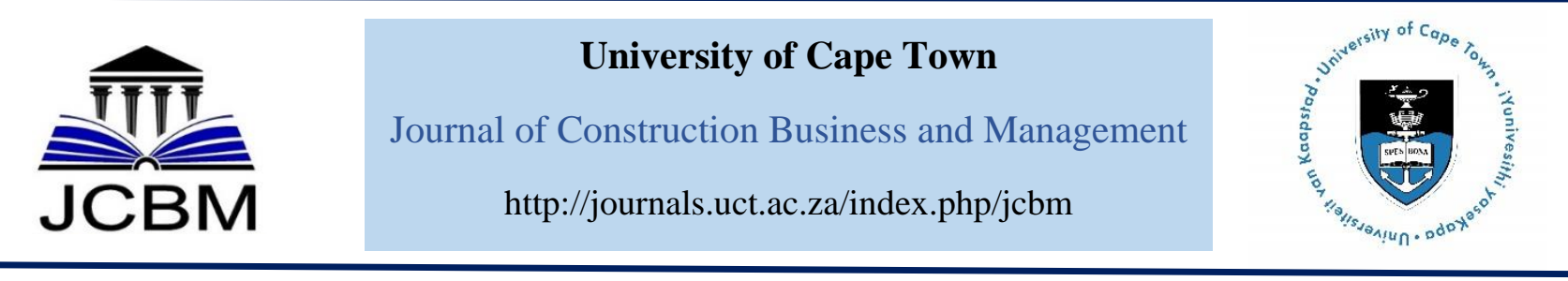

\title{
Relationship Between Organisational Effectiveness and Project Performance of SME Contractors: a Developing Country Perspective
}

\author{
C P Ogbu ${ }^{1}$ and N. Olatunde ${ }^{2}$ \\ 1\& 2 Department of Quantity Surveying, University of Benin, Benin-City, Nigeria \\ Received 12 March 2018; received in revised form 8 June 2018 and 13 August 2018; accepted 31 January 2019. \\ https://doi.org/10.15641/jcbm.3.2.568
}

\begin{abstract}
Organisational effectiveness (OE) theory provides a veritable framework for examining organisational performance. This theory has, however, made a very little inroad into construction management literature, and there are limited discussions on the domains within which construction firms can measure their OE. Besides this, the extent to which corporate OE determines a contractor's project performance is not fully understood, primarily, in the small and medium-sized enterprise (SME) contractor context. Based on data from 53 projects in higher institutions in Nigeria, this study evaluated the measures of corporate OE of SME contractors and examined the contributions of the corporate OE of the firms to their project performance. By factor analysis, it was discovered that the SME contractors' corporate OE can be measured using corporate advantage, firm experience, firm certification and firm owner background. Using canonical correlation, a significant relationship was found between the $\mathrm{OE}$ of the firms and the measures of project performance. The analysis further revealed that project cost and quality performances are bettered by increases in firm certification and experience, although time performance tends to worsen as a result. In addition to identifying the domains for measuring an SME contractor's OE, this study shows that better firm experience does not necessarily improve a contractors' project time performance. Construction stakeholders and the public should beware of firms that only boast of an excellent corporate advantage and ownership by prominent persons in the society, but without adequate experience and certification.
\end{abstract}

Keywords: Corporate Advantage, Firm Experience, Project Performance

\section{Introduction}

Organisational effectiveness $(\mathrm{OE})$ is a critical concept in organisational theory (Upadhaya, Munir, \& Blount, 2014). As the ultimate criterion variable in empirical organisational studies, OE is generally accepted to be a potent theoretical tool for evaluating firm processes, structures and outcomes (Martins \& Coetzee, 2009; Upadhaya et al., 2014). The sparse use of OE theory in assessing construction firms' project performance in construction management literature partly motivated this study (e.g. Kiziltas, Dikmen, \& Birgonul, 2003; Love \& Skitmore, 1996). Construction firms are critical to the attainment of economic development by any nation, being the constructors of the infrastructure required to drive growth in other sectors of an economy. This genre of firms are often chided for being slow in the execution of projects (Aibinu \& Jagboro, 2002), unethical (Alutu, 2007), having poor safety performance ( $\mathrm{Ng}$, Cheng \&

\footnotetext{
${ }^{1}$ Corresponding Author.

Email address: chukwuemeka.ogbu@uniben.edu
}

Skitmore, 2005), lagging in innovation (Winch, 1998; Dainty et al. 2017) and threatened by high employee turnover rates (Loosemore, Dainty \& Lingard, 2003). A robust assessment of the effectiveness of construction industry firms that is grounded in OE theory will potentially point out the organisational traits responsible for the identified issues. This study was conceived to contribute in this regard.

Also, it is firmly established that the problem of low OE tend to be more prevalent in terms of spread and intensity among small and medium-sized enterprise (SME) construction firms (Dainty, et al. 2017; Acar et al. 2005; Nelson et al. 2007). Clough, Sears and Sears (2000) and Enshassi, Al-Hallaq, and Mohamed (2006) asserted that construction contracting businesses have the secondhighest failure rate of any business, exceeded only by restaurants. In developing countries, the organisational deficiencies of SME contractors are often more pronounced due to the business environment of these 
nations (Ofori 2000; Kheni, Gibb \& Dainty, 2010; Ogbu, 2018). Frequently, the firms are owner-managed; they show a preference for poorly trained labour (Dainty et al. 2017) and have low appurtenances of formality. Construction SMEs in developing countries are comparatively poorly studied (Kulemeka, Kululanga and Morton, 2015). Conceptually, the organisational deficiencies of SME contractors have implications for their levels of project performance. It is easily noticeable that irrespective of those deficiencies, most studies evaluating project performance in developing countries hardly consider the effectiveness of the contractor's organisation as a critical contributory factor (for instance Ameh, Soyingbe \& Odusami, 2010; Kulemeka et al. 2015; Odediran \& Windapo, 2014). This is unlike firms in developed countries for which Brush, Bromiley, and Hendrickx (1999) presented broad arguments for and against the explanatory relevance of corporate efficiency variables to business segment performance. It is intended to narrow this research gap in the context of developing countries in this study.

SMEs in developing economies are strategic to the development of the construction sector. They foster the spread of construction activities and the development of a country's construction industry (Ofori, 1991; Abor \& Quartey, 2010). Construction SMEs are a good source of employment due to the ease with which they can be established, and their labour-intensive nature (Cook \& Nixson, 2000). Usually, the definition of SMEs differs in different jurisdictions (Dainty et al. 2017). Based on the headcount of employees of the firms, European Commission (2003) divided firm sizes into the ranges of $<10$ (micro), $<50$ (small) and <250 (medium). In a Ghanabased study, Kheni et al. (2010) conceived SMEs as $\geq 30$ $\leq 199$ employees (medium), $\geq 10 \leq 29$ employees (small) and $\leq 9$ employees (micro) firms. It may aid future studies to define SMEs differently for firms in different industries. For instance, Dainty et al. (2017) noted that the European Commission's (2003) definition renders almost all construction firms micro and small firms. For Nigeria, Bank of the Industry (2018) categorised SMEs as $\leq 10$ employees (micro), $>11 \leq 50$ employees (small) and $>50 \leq$ 200 employees (medium), which is not too different from the classification of the European Commission (2003). Employees in a typical indigenous construction firm in Nigeria hardly exceed 200 persons. Previous studies classified indigenous construction firms in Nigeria as SMEs as a result (Ogbu, 2011; Idoro, 2012).

Nigerian indigenous SMEs are given a preference in the award of public sector contracts (the Federal Republic of Nigeria, 2007). Yet, they are also known to have poor project outcomes in terms of quality, cost and speed, and to lack the capacity to handle complex projects (Ofori, 1991; Idoro, 2010; Ibrahim, Githae \& Stephen, 2014). Most studies (Hwang et al. 2009; Song, Mohamed, and AbouRizk, 2009) investigating the project performance of construction firms focused on predicting only one variable at a time. This ignores the reality that these variables alter simultaneously and relatedly, rather than independently, and variations in one of the variables affect the others. For instance, when cost performance changes, it is likely to affect quality and time performances. In a United Kingdom-based study,
Alzahrani and Emsley's (2013) modelled the probability of construction professionals' agreement that contractor attributes affect project success using ordinal logistic regression. A research gap exists to model the relationship between contractors' OE and project performance (measured at interval and ratio scales) using canonical correlation. Such an analysis will retain the relatedness among the performance measures (quality, time and cost), and offer insights into their behaviour under the influence of a construction SME's corporate level OE (based on the firms' owners' and the firms' characteristics). This result will be beneficial to construction clients in selecting contractors (Khosrowshahi, 1999), and to the contractors themselves in improving on their firm effectiveness. This research, therefore, evaluates the measures of corporate OE of SME contractors, and determines the contribution of the latter on the project performance of SME contractors.

\section{Organisational Effectiveness}

OE has been defined in different ways in literature. Georgopoulos and Tannenbaum (1957:2) explained that OE indicates how well an organisation is doing. The study defined $\mathrm{OE}$ as, "the extent to which an organisation as a social system, given certain resources and means, fulfils its objectives without incapacitating its means and resources and without placing undue strain upon its members." This view of OE emphasises goal achievement and aligns with Etzioni's (1964) assertion that OE is the degree of goal realisation. However, it also highlights the state of the organisation's "means" (processes) and "resources" at the time of goal realisation. Argyris (1964: 123) expressed $\mathrm{OE}$ as a condition where the firm increases its outputs with constant or decreasing inputs or has a continuous output with decreasing inputs. Holbeche (2012) did not dispute these definitions but suggested that the focus should not only be on the short-term results, but also on how the result is gotten through people.

Two distinctive perspectives to $\mathrm{OE}$ are revealed by the preceding definitions - the input perspective and the output perspective. These two perspectives shall be explored in this study. Yukl (2008) lumped these perspectives together by describing $\mathrm{OE}$ as the extent to which an organisation can survive, perform its mission, and maintain favourable earnings, financial resources, and asset value. The input side of $\mathrm{OE}$ comprises the firm's internal composition, resources and socio-economic system (corporate $\mathrm{OE}$ ), while the output side consists of the results obtained from the deployment of those resources in the socio-economic context of the firm. In the end, a firm's bargaining position in a given environment is an expression of the efficiency of the firm's corporate OE (Yuchtman \& Seashore, 1967). Kiziltas et al. (2003) noted that in the construction industry, the activities taking place in the firm at the corporation level usually is responsible for the value created at the site level. The effectiveness of a construction firm can be judged from three perspectives, namely: 1) efficiency and adequacy of internal processes relative to the competition, 2) firm performance, 3) project performance. Cameron (1980) christened these processes as the "system resource, internal process and organisation approaches", "goal- 
oriented approach" and "strategic constituency approach" respectively. Using the system resource, internal process and organisation approach, for instance, one can carry out a study to investigate the adoption of best practices within a construction firm. Such a study will typically use multiple criteria to examine the efficiency of issues like leadership within the firm, human resource management, organisational culture and climate, and so on. Studies focusing on firm performance (goal-oriented approach) will probably look at annual turnover, a number of employees, profit to asset ratio, profit before tax, employee turnover, among others (Darwisha, Singh \& Mohamed, 2013). These performance indicators do not reflect the firm's performance in any individual project but measure the aggregate outcome of the firm's business activities in a given period. Contrastingly, project performance measures relate to the outcome of individual projects handled by the firm from the client's (strategic constituency's) perspective. Common variables in this type of assessment include time, quality and cost. This study is interested in how corporate level resources relate to the project performance of SME contractors.

Kiziltas et al. (2003) used a plethora of variables classified as an organisation and its subsystems, business environment, macro environment and general characteristics in their assessment of the OE of Turkish construction firms. Contrastingly, it is argued here that the external environment influences a firm's project performance by affecting the firm at the corporate level given that entrepreneurs will usually select firm resources based on socio-economic constraints (Buyinza and Bbaale, 2013) (see Figure 1). Socio-economic context is a determinant of the characteristics of persons that can own firms and the characteristics of the firms themselves. In some climes, for example, women may not own construction firms due to their social status. Likewise, a certain level of industry work experience or educational qualification is required of persons seeking to register as contractors. Other choices in terms of a firm's internal resources will also be detected by the particular requirements of the industry in which the firm intends to operate. Thus, the impact of external factors on the project performance of firms is moderated by the firm's internal resources and corporate resilience. This research focuses on how the site level performance of the firms (OE measured from the client's perspective) is affected by the corporate $\mathrm{OE}$ of the SME contractors (measured from the contractor's perspective).

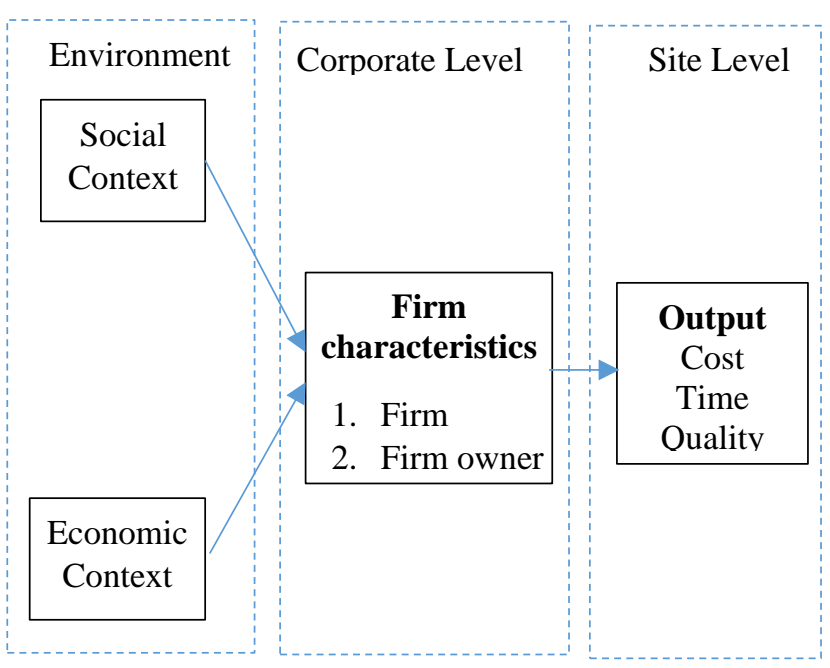

Figure 1 Conceptual Framework of the Study

\section{Measures of SME Contractors' Organisational Effectiveness}

Disagreements existed earlier in OE literature on the best domain of an organisation to focus $\mathrm{OE}$ assessment, (Cameron, 1986; Love and Skitmore, 1996), but this should no longer be the case. Organisations exist for certain purposes and are intended to affect and be affected by some stakeholders or constituencies. This heterogeneity in terms of "objects, subjects and outcomes" creates asymmetry in the applications of the OE theory for the assessment of firms in different industries (Cameron, 1980). Cameron and Whetten (1983) and Cameron (1986) posed seven questions to help evaluators to delimit their variables when assessing a firm's OE. The questions and their answers relative to this study have been stated in Table 1 .

Table 1: Critical questions to answer before undertaking OE assessment

\begin{tabular}{lll}
\hline S/N & Question & Answers \\
\hline 1 & From whose perspective is effectiveness being assessed? & From the client's perspective \\
\hline 2. & On what domain of activity is the assessment focused? & $\begin{array}{l}\text { Firm internal (corporate level) resources and } \\
\text { processes, and project performance }\end{array}$ \\
\hline 3. & What level of analysis is being used? & Firm and individual project levels \\
\hline 4. & What is the purpose for assessing effectiveness? & Determination of influence of firm corporate \\
& OE on project outcome & Short term \\
\hline 5. & What time frame is being employed? & Organisational and project data - measured at \\
\hline 6. & What type of data are being used for assessments? & Project performance (client's perspective) \\
\hline 7 & What is the referent against which effectiveness is judged? &
\end{tabular}

Yuchtman and Seashore (1967) suggested that the assessment of OE must be in terms not of any single criterion but an open-ended multidimensional set of criteria. Kiziltas et al. (2003) followed this suggestion but focused on medium-to-big sized contractors, some of who operated in international markets, thus differentiating it from the context of this study. Sexton, Barrett and Aouad (2006) noted that small and large construction companies 
are different species that live in different business habitats. An issue that usually constrains the study of developing country construction SMEs is the dearth of quality data for such an undertaking (Cook \& Nixson, 2000). Undeniably, the problem posed by this challenge is outweighed by the need to understand how the internal workings of firms influence their project performance and guide future research investigations and policy decisions. The choice of variables included in this study was dictated by prior expectations based on theory, measurability, and previous empirical studies (Lopez-Garcia and Puente, 2006). A firm's corporate $\mathrm{OE}$ is regarded as decipherable from 1) the firm owner's characteristics (Madhoushi \& Ghaedi, 2013) and 2) the firm's characteristics (Mohd, 2005; Dean, Bülent \& Christopher, 2000) (see Table 2). First, in developing countries' construction SMEs, firm owners are hardly distinguishable from the firms themselves, and majority of the workers may be the family members of the owner (Kheni et al., 2010). This perspective is missing in some studies like Tam (1992). Clients tend to perceive SME contractors from the image of their owners, and firm owners' ethnicity and other qualities are sometimes considered necessary during tendering (see Madhoushi and Ghaedi, 2013; Le et al. 2014). Firm owners bear the firm's risks, and so are often constrained to innovate their firms in response to the dynamic market conditions (Barrett \& Sexton, 2006). There is a dearth of literature evidence of the relationship between firm owner characteristics and construction project outcome. As a result of this, firm owner characteristics obtained from previous studies were used in this study as proxies for corporate OE.

Legally, the firms are different from their owners. Hence firm characteristics were also used as proxies of OE. Measures of firm characteristics are the attributes of the firms (for example firm age and size), which are considered important determinants of organisational performance in the general management literature (Cressy, 1996; Geroski, Mata \& Portugal, 2003). Table 2 shows the firm and firm-owner characteristics used to proxy OE. Since OE is context-dependent, the choice of measures of corporate $\mathrm{OE}$ was extended to those that specifically relate with SME contractors. For example, the level to which a firm is categorised by the Bureau of Public Procurement (BPP) in Nigeria should correlate with the firm's performance at the site level. The BPP's categorisation and registration of companies in the construction industry are obtained by weighing the firms' manpower, equipment and financial capacities. The categories of registration range from $\mathrm{A}$ to $\mathrm{E}$ in descending order of capacity, and it is expected that firms in the higher categories will perform better at the site level (BPP, 2018) given their levels of resources. Besides this, Nigerian SME contractors are statutorily expected to be registered and to pay subscriptions to institutions like the National Pension Commission (NPC) and the Industrial Training Fund (ITF). Although registration with these bodies is not directly linked to the firms' ability to deliver projects at the site levels, they, nevertheless, matter in their corporate OE. Not registering with these bodies will severely limit a firm's ability to win jobs and, consequently, experience, because such firms are excluded from projects in which the Federal Government of Nigeria has a $\geq 30 \%$ stake. Likewise, such firms will hardly attract the highly experienced construction personnel needed for performance at the site level.

Firm owner characteristics such as the age of the owner of a firm affect the flow of construction activities on site, which will ultimately impact on project performance. Older persons tend to be slower and more risk-averse, so their behaviour may retard the speed of construction on site. Additionally, an SME contractor owned by an experienced manager who owns other businesses will have an edge over firms owned by individuals without similar ownership. SME contractor owners sometimes also own blocks, kerbs or paint making companies. Managers of SME contractors who own such other businesses will leverage those businesses to support the site-level performance of their construction companies when a need arises. Ljubojevic, Ljubojevic and Maksimovic (2013) noted that such capabilities could enable the firm to produce standard goods at a lower cost or produce higher-quality goods at the same standard cost. In another instance, projects being executed by firms owned by women will suffer hitches because of the sociocultural status of women. It will be difficult, for example, for a woman to control the men-dominated construction artisans to influence project performance significantly.

Overall, a firm's "corporate advantage", that is, how its owner combines hard-to-imitate resources across different businesses to create an integrated whole will influence its performance at the project level (Collis \& Montgomery, 1998; Rozemeijer, 2000). Firms will always differ in terms of their possession of the determinants of corporate OE discussed above, which will ultimately relate to their abilities to perform on site. Each firm's corporate advantage is unique and difficult to copy by its competitors (Chen, Lai \& Wen, 2006).

It is hypothesized that the SME contractor variables in Table 2 will have a significant relationship with the firm performance variables presented in Table 4 .

\section{Project Performance}

There are various project performance indices (De Wit, 1988; Sawacha, Naoum, \& Fong, 1999; Bassioni, Price, \& Hassan, 2004; Takim \& Akintoye, 2002). Drawing from previous studies, Cheng, Li and Love (2000) listed the measures shown in Table 3 as indicators of project performance. Love and Holt (2000) noted that performance measures should focus on all company stakeholders' interests, not necessarily financial ones. Cho, Hong and Hyun (2009) explained project performance variables in terms of being either qualitative or quantitative. The qualitative performance indices measure the quality using turnover quality or system quality, while the quantitative performance indices evaluate project cost and time. This latter approach was adopted in this study (see Table 4). Variables for the measurement of project performance in this study were project cost, quality and time obtained from the clients as indicated in Table 1. Stare (2011) pointed out that these performance expectations are not achieved in most construction projects. Juxtaposing the contractorprovided OE of the firm (Table 2) against the client's data on the contractor's performance (Table 4) tells how the 
firm's corporate OE has resulted in site-level performance. Given the dissatisfaction with the sole use of financial measures in performance measurement (Mbugua et al. 1999), a mix of financial and non-financial measures was used in this case. Table 4 shows the three project performance criteria used in this study, how they were measured and the benefits of their use.

Table 2: Proxies of construction SME organisational effectiveness

\begin{tabular}{|c|c|c|c|}
\hline Characteristic & Code & Measurement & Sources \\
\hline \multicolumn{4}{|l|}{ Firm Owner } \\
\hline Age of owner & $\mathrm{X} 1$ & Actual age at last birthday & Cressy (1996) \\
\hline Education & $\mathrm{X} 2$ & $\begin{array}{l}\text { High }=2 \text { (for M.Sc holders and above), } \\
\text { Intermediate }=1 \text { (for HND/B.Sc holders), otherwise, } 0\end{array}$ & Egesa (2010) \\
\hline $\begin{array}{l}\text { Professional } \\
\text { qualification }\end{array}$ & $\mathrm{X} 3$ & $\mathrm{NIQS}=1, \mathrm{NIA}=2, \mathrm{NIOB}=3, \mathrm{NSE}=4, \mathrm{NONE}=0$ & BPP (2018). \\
\hline $\begin{array}{l}\text { Construction } \\
\text { industry work } \\
\text { experience }\end{array}$ & $\mathrm{X} 4$ & Number of years of work in the construction industry & $\begin{array}{l}\text { Coleman, } \\
\text { Cotei and Farhat (2013); } \\
\text { Madhoushi and Ghaedi (2013 }\end{array}$ \\
\hline Gender & $\mathrm{X} 5$ & Male $=1$ otherwise, 0 & Kalleber and Leicht (1991) \\
\hline $\begin{array}{l}\text { Previous self- } \\
\text { employment }\end{array}$ & X6 & Yes $=1$, no $=0$ & $\begin{array}{l}\text { Frankish et al. (2007); } \\
\text { Knut et al. (2007) }\end{array}$ \\
\hline
\end{tabular}

\begin{tabular}{|c|c|c|c|}
\hline Ethnicity of owner & $\mathrm{X} 7$ & "1" if the owner of firm is from the Edo State, "0" otherwise & Nafziger and Terrel (1996) \\
\hline $\begin{array}{l}\text { Ownership of other } \\
\text { business(es) }\end{array}$ & $\mathrm{X} 8$ & Yes $=1$, no $=0$ & Kelleber and Leicht (1991) \\
\hline CEO Duality & $\mathrm{X} 9$ & If the owner of the firm is also the $\mathrm{CEO}=1$, otherwise $=0$ & $\begin{array}{l}\text { Yang and Zhao (2014); } \\
\text { Baselga-Pascual et al. (2014 }\end{array}$ \\
\hline
\end{tabular}

Firm

\begin{tabular}{|c|c|c|c|}
\hline Firm age & $\mathrm{X} 10$ & Actual age of business in years & $\begin{array}{l}\text { Cressy, (1996), } \\
\text { Geroski et al. (2003) }\end{array}$ \\
\hline Firm Size & $\mathrm{X} 11$ & Natural Logarithm of a firm's permanent staff in 2014 & Cefis and Marsili (2004) \\
\hline Technology use & $\mathrm{X} 12$ & Amount spent on ICT per month & Egesa (2010) \\
\hline Firm location & $\mathrm{X} 13$ & $\begin{array}{l}\text { Dummy variable: } 1=\text { if firm is located in the state capital, } \\
\text { otherwise, } 0\end{array}$ & Farinha (2005) \\
\hline Firm experience & $\mathrm{X} 14$ & $\begin{array}{l}\text { Score based on types of projects in which the firm have } \\
\text { participated }\end{array}$ & $\begin{array}{l}\text { Shaver et al. (1997) } \\
\text { Dimov and de Holan's (2010) }\end{array}$ \\
\hline Personnel expertise & $\mathrm{X} 15$ & $\begin{array}{l}\text { Number of personnel that are fully registered with the } \\
\text { professional body }\end{array}$ & \\
\hline $\begin{array}{l}\text { Number of } \\
\text { registrations }\end{array}$ & $\mathrm{X} 16$ & $\begin{array}{l}\text { Number of organisations with which the firm is registered } \\
\text { including: federal Inland Revenue Service, Pension } \\
\text { Commission, Industrial Training Fund, Bureau of Public } \\
\text { Procurement, Corporate affairs commission, private client } \\
\text { bodies and public sector procuring entities, and others }\end{array}$ & Babajide (2012) \\
\hline
\end{tabular}

Group membership $\mathrm{X} 17 \quad \begin{aligned} & 1 \text { if the company is a member of a large group of } \\ & \text { companies, otherwise } 0\end{aligned}$
$\begin{aligned} & \text { Founding } \\ & \text { condition/initial } \\ & \text { size }\end{aligned}$

Source: Various authors

NIQS=Nigerian Institute of Quantity Surveyors, NIA=Nigerian Institute of Architects, NIOB=Nigerian Institute of Building, NSE=Nigerian Society of Engineers, HND=Higher National Diploma, CEO=Chief executive officer, ICT=Information and Communication Technology 
Table 3 Project performance measures and their benefits

\begin{tabular}{|c|c|c|c|c|}
\hline $\mathbf{S} / \mathbf{N}$ & Criterion & Measure & Measuring Unit & Benefit \\
\hline 1. & Cost-effectiveness & Cost variation & Actual cost/budgeted cost & Improve cost savings for client \\
\hline 2. & Quality & $\begin{array}{l}\text { Rejection of work } \\
\text { Client satisfaction } \\
\text { Quality of work }\end{array}$ & $\begin{array}{l}\% \text { sample rejections } \\
\text { Number of claims by client } \\
\text { Number of claims by } \\
\text { contractors }\end{array}$ & $\begin{array}{l}\text { Improve client confidence } \\
\text { Increase client satisfaction } \\
\text { Increase construction } \\
\text { durability }\end{array}$ \\
\hline 3. & Schedule & Schedule variation & $\begin{array}{l}\text { Actual duration/planned } \\
\text { duration }\end{array}$ & Reduce additional expenses \\
\hline 4. & Scope of work & Change in scope of work & Change orders/budgeted cost & Reduce additional expenses \\
\hline 5. & Profit & Profit variation & Actual profit/projected profit & Increase income \\
\hline 6. & $\begin{array}{l}\text { Construction } \\
\text { process }\end{array}$ & $\begin{array}{l}\text { Safety } \\
\text { Re-work }\end{array}$ & $\begin{array}{l}\text { Number } \\
\text { accidents?100/Total number } \\
\text { of workers } \\
\text { Rework MH/total MH }\end{array}$ & $\begin{array}{l}\text { Develop safety practice to } \\
\text { manage risks } \\
\text { Reduce wasted work }\end{array}$ \\
\hline & Others & $\begin{array}{l}\text { Litigation } \\
\text { Tender efficiency }\end{array}$ & $\begin{array}{l}\text { Expense of litigation } \\
\text { Success rates }\end{array}$ & $\begin{array}{l}\text { Reduce cost } \\
\text { Generate income }\end{array}$ \\
\hline
\end{tabular}

Source: Cheng, Li and Love (2000)

Table 4: Project performance (OE) variables uses in the study

\begin{tabular}{lllll}
\hline S/N & Criterion & Measure & Measuring Unit & Benefit \\
\hline 1. & $\begin{array}{l}\text { Cost } \\
\text { effectiveness }\end{array}$ & Cost variation & $\begin{array}{l}\text { Final Account value/Initial } \\
\text { contract sum }\end{array}$ & Improve cost savings for client \\
\hline 2. & Quality & Quality of Work & Number of re-works & $\begin{array}{l}\text { Increased client satisfaction and project } \\
\text { usefulness }\end{array}$ \\
\hline 3. & Time & $\begin{array}{l}\text { Schedule } \\
\text { variation }\end{array}$ & $\begin{array}{l}\text { Planned duration/Actual } \\
\text { duration }\end{array}$ & Early project use \\
\hline
\end{tabular}

\section{Methodology}

This study focused on contractors and projects in public tertiary institutions in Edo State Nigeria from which the required data could be obtained. BPP (2015) showed that most complaints on construction procurement emanate from projects in the Ministry of Education. Primarily, this study sought to relate measures of a construction firm's OE to its performance at the project site level. Both OE of the firms and their project performances exist independently of the social conceptions of them. In consequence, an objectivist ontological stance was adopted for this study (Grix, 2002; Panas \& Pantouvakis, 2010), and only quantitative data were gathered for analyses to address the objectives of the study. The population of the study consisted of contractors and clients/consultants that participated in construction projects in the tertiary institutions. The contractors were requested to provide factual data on their firms, and the clients/consultants were requested to supply accurate data on project outcomes. It was, however, not possible to get already prepared sample frames containing the names of the projects, their consultants and contractors from the institutions covered by the study. This type of challenge is known to exist in the construction industry of most developing countries as a result of lapses in recordkeeping (Cook \& Nixson, 2000).

Consequently, the sample frame was formed from the data obtained on an ad hoc basis from the institutions' physical planning and estates divisions. In all, 76 projects were identified for which the names and verifiable contacts of the consultants and contractors could be found. The projects that met the criteria happened to be those completed between 2010 and 2017. The participants in the 76 projects formed the population of the study. Thus, an interpretivist epistemology was adopted in gathering the study's data. This aligns with Otokiti (2005), Dainty (2008) and Patton (1990) who posited that the design of a study depends on its context, and that research is an art of the possible.

The survey targeted all the firms involved. The questionnaire mainly sought the SME construction firms' OE measures shown in Table 2, while the consultants/clients for the projects were requested to fill out tables containing the project performance criteria using the measuring units stated in Table 4.

In the process of data collection, it was discovered that some construction firms had carried out more than one project in the study area. During the analysis, the firm owner and firm characteristics were repeated for the number of projects in which they participated. This made the criteria and explanatory variables to have the same number of cases, even though the number of projects covered was higher than the number of contractors.

\section{Data Analysis}

\subsection{Factor analysis}

Factor analysis reduces a set of variables into a fewer number of non-correlated factors that can represent the original variables (Fellows \& Liu, 1997; Iyer \& Jha, 2005). Before conducting the canonical correlation, the twenty $\mathrm{OE}$ variables were reduced to a more parsimonious set of variables using factor analysis. Two things were achieved with the process: first, the latent factors accounting for most of the variance in the data set were identified and named, and secondly, the factors were saved for use in the canonical correlation. 
Although Costello and Osborne (2005) noted that the ratio of the number of cases to the number of variables for an excellent factor analysis should be large $(\geq 5: 1)$, noticeably, authors of construction management studies have tended to ignore this rule (Hardcastle, et al. 2005; Fox \& Skitmore, 2007; Zhao et al. 2014). Plausibly, this is as a result of the low return of questionnaires in construction management studies. The factor analysis in this study was based on a case to variables ratio of 2.65:1.

The data were tested for factorability using the Kaiser-Meyer-Olkin (KMO) measure of sampling adequacy and Bartlett's test of sampling sphericity. For good factor analysis, the KMO test should give $\geq 0.6$, while Barlett's test of sphericity should be significant at $\alpha=0.05(p<0.05)$ (Fellows \& Liu, 1997; Field 2005). The factor analysis was conducted by principal component method, with varimax rotation using the Statistical Package for Social Sciences (SPSS) version 22. Yong and Pearce (2013) and Costello and Osborne (2005) opined that the number of factors could be determined based on a threshold eigenvalue of 1 , and that a structure loading of $\geq 0.3$ can be considered strong enough for interpretation. However, following Leung et al. (2005), only variables with loadings of $\geq 0.50$ were regarded as having loaded highly under each factor in this study. This also goes to compensate for the low cases-to-variables ratio of the study.

\subsection{Canonical Correlation}

Canonical correlation was used to analyse the relationship between $\mathrm{OE}$ of the SME contractors and their project performance. Canonical correlation analysis aims to find the best linear combination between two multivariate datasets that maximises the correlation coefficient between them (Malacarne, 2014). It extends bivariate correlations by allowing for two or more dependent variables (on the left-hand side) to be related with two or more independent variables (on the right-hand side).

Montabon, Sroufe, and Narasimhan (2007) used this technique in relating the environmental management practices of firms to their performance. Particularly, canonical correlation closely mimics the real-life situation where several criterion variables are being influenced by several independent variables simultaneously (Shafto, Degani \& Kirlik, 1997). It is important to model project performance criteria simultaneously since the achievement of one criterion could affect the success of the others. For instance, when the cost is reduced, quality may be compromised, or schedule growth may occur. Canonical correlation tests the hypothesis that the two sets of data - the OE of the firms and their project performance are independent and shows the contribution of each variable to the relationship. Canonical correlation is flexible, and does not impose the type of data restrictions associated with multiple regression analysis; it allows for the use of both metric and non-metric data in the correlation (Hair, Anderson, Tatham and Black, 1998). Sherry and Henson (2005) observed that Wilk's $K$ is the most widely used test criteria for the model fit in the canonical correlation analysis. For a significant relationship to be inferred, the p-value of the Wilk's $\Lambda$ test must be $<0.05$. The contribution of the variables was interpreted based on redundancies and canonical loadings.
Canonical structure (rs) and standardised coefficient loadings cut-off point of $\geq 0.30$ was adopted (Crum, Lund \& van Auken, 1987; Munro, 2005; Mendes, da Sylva \& Santos, 2012). Hence, under each canonical root, variables not loading up to the cut-off point were considered insignificant. The squares of the canonical structure loadings $\left(\mathrm{r}^{2}\right)$ were also computed, which captured the proportion of linear variance shared between an observed variable and its group's canonical variate (Sherry \& Henson, 2005). Redundancies of up to 0.25 were considered to be substantial, given previous studies (Montabon et al. 2007; Keramati, 2007), and the peculiarities of this research.

Rencher (2002) argued that standardised coefficients show the contribution of each variable in the presence of other variables. Hence, the standardised coefficients of the variables were equally reported. The stability of the canonical correlation result was tested by omitting the explanatory variables one after another, and checking the changes in their loadings under each significant canonical root (Hair et al. 1998; Dattalo, 2014).

\section{Results}

Out of the 76 pairs of the questionnaires sent out to the respondents, only 53 pairs of acceptably filled questionnaires were returned.

Table 5 shows the types of projects covered by the study and the procurement methods used. The number of projects using the design-bid-build approach was more in number $(n=42)$, and most of the projects were new buildings $(n=31)$. The projects covered the period 2010 to 2017, although this was not the yardstick used in the selection of projects for the study. Majority of the respondents were civil engineers $(n=14), 15$ were project engineers, and most $(n=21)$ have $>10 \leq 20$ years construction industry work experience (Table 6). The profile of the respondents gave confidence that the respondents could offer reliable information for the study. Table 7 shows the means and standard deviations of the performance variables studies. The cost-effectiveness, which was measured as the ratio of the final account value to the initial contractor sum had a mean of 1.4509 and a standard deviation of 2.56307 which means that on the average, the projects covered exceeded the initial budget by about $45 \%$. Likewise, on the average, about nine rework cases were reported per project, and planned-toactual duration ratio averaged 0.66 .

On testing the factorability of the data, the KMO measure of sampling adequacy and Bartlett's test of sampling sphericity yielded acceptable values: .819 and $\mathrm{X} 2=859.714(\mathrm{df}=190, \mathrm{p}=0.000)$ respectively. Four factors emerged, which cumulatively explain $71.540 \%$ of the variance in the data set (Table 8 . The four factors were determined from the Eigenvalue of 1 . The first factor is dominated by variables relating to an SME contractor's advantage over similar firms at the corporate level, such as ownership of other business, group membership, and organisational structure. For this reason, Factor 1 was labelled "corporate advantage" factor. Factor 2 was dominated by variables relating to experience such as firm age, firm experience, construction industry work experience of the owner, among others. Factor 2 was, 
therefore named the "firm experience factor". Factor 3 was called the firm certification factor since the level of firm registration, and a number of records of firm loaded significantly under the factor. Lastly, Factor 4 under which ethnicity of owner loaded highly was christened "firm owner background" factor.

Given that some variables had factor loadings of $<0.50$, the factor analysis was repeated to test the stability of the loadings under the respective factors. This has been reported in Table 9. The KMO measure of sampling adequacy and Bartlett's test of sampling sphericity again yielded acceptable values: .774 and $\mathrm{X} 2=560.481$ $(\mathrm{df}=105, \mathrm{p}=0.000)$ respectively. Similarly, four factors emerged, which cumulatively explain $73.209 \%$ of the variance in the data set. As shown in Table 9, the result of this analysis substantially validates the result in the first factor analysis already reported on, with the exception that the founding condition/initial size (x18) which initially loaded positively under the first factor (corporate advantage) now loads negatively under the second factor (firm experience). Hence, while it is accepted that the variable is relevant in the assessment of the OE of the SME contractors, the exact domain of its contribution could not be ascertained in this study

Table 5: Type of projects covered by the study

\begin{tabular}{llc}
\hline S/N & Project Type & Number \\
\hline 1. & New Civil infrastructure & 10 \\
\hline 2. & New Building & 31 \\
\hline 3. & $\begin{array}{l}\text { Maintenance/Repairs of buildings or } \\
\text { civil infrastructure }\end{array}$ & 12 \\
\hline Total & \multicolumn{1}{c}{ Type of Procurement } \\
\hline \multicolumn{2}{c}{ Design-Bid-Build } & 53 \\
\hline 4. & Design and Build & 42 \\
\hline 5. & & 53 \\
\hline Total &
\end{tabular}

Table 6: Respondent characteristics

\begin{tabular}{llc}
\hline S/N & Respondent's Professions & Number \\
\hline 1. & Civil Engineering & 14 \\
\hline 2. & Architecture & 11 \\
\hline 3. & Building & 4 \\
\hline 4. & Quantity Surveying & 13 \\
\hline 5. & Mechanical/Electrical Engineering & 6 \\
\hline 6. & None construction professions & 5 \\
\hline Total & 53 \\
\hline
\end{tabular}

Title/Position in the Firm

\begin{tabular}{|c|c|c|}
\hline 1 & Project Engineer & 15 \\
\hline 2 & Project/contract Manager & 12 \\
\hline 3 & Chief executive officer & 13 \\
\hline 4 & Procurement Engineer & 3 \\
\hline 5 & Cost manager/Quantity Surveyor & 9 \\
\hline 6. & Builder & 1 \\
\hline Total & & 53 \\
\hline \multicolumn{3}{|c|}{ Construction Industry Work Experience } \\
\hline 1 & $\leq 10$ years & 17 \\
\hline 2 & $>10 \leq 20$ years & 21 \\
\hline 3 & $>20$ years & 15 \\
\hline Total & & 53 \\
\hline \multicolumn{3}{|c|}{ Number of Years with the Present Firm } \\
\hline 1 & $\leq 5$ years & 23 \\
\hline 2 & $>5 \leq 10$ years & 14 \\
\hline 3 & $>10 \leq 20$ years & 10 \\
\hline 4. & $>20$ years & 6 \\
\hline Total & & 53 \\
\hline
\end{tabular}

Table 7: Descriptive Statistics of the Criterion Variables

\begin{tabular}{lccc}
\hline Performance Indices & N & Mean & $\begin{array}{c}\text { Std. } \\
\text { Deviation }\end{array}$ \\
\hline Cost Effectiveness & 53 & 1.4509 & 2.56307 \\
Quality & 53 & 8.9838 & 11.58406 \\
Time & 53 & 0.6646 & 0.68344 \\
Valid N (listwise) & 53 & & \\
\hline
\end{tabular}

Table 8: Factor Analysis Results

\begin{tabular}{|c|c|c|c|c|c|}
\hline \multirow[b]{2}{*}{ Code } & \multirow[b]{2}{*}{ Variable } & \multicolumn{4}{|c|}{ Component } \\
\hline & & $\begin{array}{l}\text { 1: Corporate } \\
\text { Advantage }\end{array}$ & $\begin{array}{c}\text { 2:Firm } \\
\text { Experience }\end{array}$ & $\begin{array}{c}\text { 3:Firm } \\
\text { Certification }\end{array}$ & $\begin{array}{l}\text { 4: Firm Owner } \\
\text { background }\end{array}$ \\
\hline x6 & Previous self-employment & 0.891 & & & \\
\hline $\mathrm{x} 8$ & Ownership of other business(es) & 0.861 & & & \\
\hline $\mathrm{x} 17$ & Group membership & 0.849 & & & \\
\hline $\mathrm{x} 11$ & Firm Size & 0.842 & & & \\
\hline $\mathrm{x} 19$ & Organisational structure & 0.834 & & & \\
\hline $\mathrm{x} 1$ & Age of owner & -0.827 & & & \\
\hline $\mathrm{x} 13$ & Firm location & -0.734 & & & \\
\hline $\mathrm{x} 2$ & Owner's level of Education & -0.701 & & & \\
\hline $\mathrm{x} 15$ & Personnel expertise & -0.64 & & -0.538 & \\
\hline $\mathrm{x} 18$ & Founding condition/initial size & 0.557 & & & \\
\hline $\mathrm{x} 10$ & Firm age & & 0.934 & & \\
\hline $\mathrm{x} 14$ & Firm experience & & 0.898 & & \\
\hline x9 & CEO Duality & & -0.869 & & \\
\hline $\mathrm{x} 4$ & Construction industry work experience & & 0.841 & & \\
\hline $\mathrm{x} 12$ & Technology use & & 0.64 & & \\
\hline
\end{tabular}


x3 Professional qualification of owner

$\mathrm{x} 20$ Level of firm registration

$\mathrm{x} 16 \quad$ Number of registrations

x7 Ethnicity of owner

x5 Gender

0.53

0.505

\begin{tabular}{lccccc}
\hline$\%$ of Variance & 33.996 & 22.928 & $8.053 \%$ & 6.563 \\
\hline$\%$ Cumulative & 33.996 & 56.925 & 64.977 & 71.540 \\
\hline Eigenvalue & 7.744 & 3.753 & 1.480 & 1.231 \\
\hline
\end{tabular}

Table 9: Second Factor Analysis Results (after omission of some variables)

\begin{tabular}{|c|c|c|c|c|c|}
\hline \multirow[b]{2}{*}{ Code } & \multirow[b]{2}{*}{ Variable } & \multicolumn{4}{|c|}{ Component } \\
\hline & & $\begin{array}{c}\text { 1: Corporate } \\
\text { Advantage }\end{array}$ & $\begin{array}{c}\text { 2: Firm } \\
\text { Experience }\end{array}$ & $\begin{array}{c}\text { 3: Firm } \\
\text { Certification }\end{array}$ & $\begin{array}{c}\text { 4: Firm Owner } \\
\text { background }\end{array}$ \\
\hline x6 & Previous self-employment & 0.891 & & & \\
\hline $\mathrm{x} 11$ & Firm Size & 0.861 & & & \\
\hline $\mathrm{x} 8$ & Ownership of other business(es) & 0.849 & & & \\
\hline $\mathrm{x} 17$ & Group membership & 0.842 & & & \\
\hline $\mathrm{x} 19$ & Organisational structure & 0.834 & & & \\
\hline $\mathrm{x} 14$ & Firm experience & -0.827 & & & \\
\hline $\mathrm{x} 10$ & Firm age & -0.734 & & & \\
\hline $\mathrm{x} 4$ & Construction industry work experience & -0.701 & & & \\
\hline $\mathrm{x} 12$ & Technology use & -0.64 & & -0.538 & \\
\hline $\mathrm{x} 18$ & Founding condition/initial size & 0.557 & & & \\
\hline $\mathrm{x} 3$ & Professional qualification of owner & & 0.934 & & \\
\hline $\mathrm{x} 20$ & Level of firm registration & & 0.898 & & \\
\hline $\mathrm{x} 16$ & Number of registrations & & -0.869 & & \\
\hline $\mathrm{x} 7$ & Ethnicity of owner & & 0.841 & & \\
\hline$\times 5$ & Gender & & 0.64 & & \\
\hline \multicolumn{2}{|c|}{$\%$ of Variance } & 33.996 & 22.928 & $8.053 \%$ & 6.563 \\
\hline \multicolumn{2}{|c|}{$\%$ Cumulative } & 33.996 & 56.925 & 64.977 & 71.540 \\
\hline \multicolumn{2}{|c|}{ Eigenvalue } & 7.744 & 3.753 & 1.480 & 1.231 \\
\hline
\end{tabular}

Using the SPSS, the factors from the first factor analysis were saved for use in the canonical correlation. A significant relationship was found to exist between the two sets of variables [Wilk's $\Lambda=.560, \mathrm{~F}(12,121.996)=$ 2.494, $\mathrm{p}=0.006]$, and two statistically significant canonical roots were derived from the analysis. Since Wilk's $\Lambda$ indicates the unexplained variance within the data set, $1-\Lambda$ gives the strength of the relationship in the model in $\mathrm{R}^{2}$ metric. Thus, the OE of the SME contractors accounted for $44 \%$ of the performance of the projects studied. Impliedly, $56 \%$ of the variance is accounted for by other factors.

The results show that Wilk's $K=.560, \mathrm{~F}(12,121.996)$ $=2.494, \mathrm{p}=0.006$ for the first canonical root, and $\Lambda=.750$, $\mathrm{F}(6,94)=2.426, \mathrm{p}=0.036$ for the second canonical root. The third canonical root was discarded for being insignificant $(K=.993, \mathrm{~F}(2,48)=0.175, \mathrm{p}=0.840)$. The canonical structure loadings $(r)$, standardized coefficients
(Coeff) and commonalities of the significant canonical roots have been reported in Table 10. Canonical root 1 shows a link between project quality $(\mathrm{r}=0.76$, coeff $=0.87)$ and time $(\mathrm{r}=-0.52$, Coeff $=-0.66)$ performances, and corporate advantage $(\mathrm{r}=0.92$, coeff $=1.02)$ and firm certification $(r=-0.37$, coeff $=-0.24)$. Except for firm certification, these variables have both high canonical structure loading and standardised canonical coefficients which confirm their importance to the canonical variates to which they belong. The signs on the canonical loadings show that corporate advantage is inversely related to the measure of project time performance, but relates directly with project quality performance. Firms with better corporate advantage tended to have more schedule growth and more rework. Indicatively, firms with better structure have not shown superiority in terms of meeting project deadlines and avoiding rework. 
Table 10: Canonical Correlation Result

\begin{tabular}{|c|c|c|c|c|c|c|c|}
\hline \multirow{2}{*}{$\begin{array}{l}\text { Set } 1 \text { Canonical Loadings } \\
\text { Variable }\end{array}$} & \multicolumn{3}{|c|}{ Canonical Root 1} & \multicolumn{3}{|c|}{ Canonical Root 2} & \multirow[b]{2}{*}{$\mathbf{h}^{2}$} \\
\hline & Coeff & $\mathbf{r}$ & $\mathbf{r}^{2}$ & Coeff & $\mathbf{r}$ & $\mathbf{r}^{2}$ & \\
\hline \multicolumn{8}{|c|}{ ORGANISATION EFFECTIVENESS } \\
\hline Corporate Advantage & 1.02 & 0.92 & 0.85 & -0.01 & 0.35 & 0.12 & 0.97 \\
\hline Firm Experience & -0.27 & 0.14 & 0.02 & 0.83 & 0.92 & 0.85 & 0.87 \\
\hline Firm Certification & -0.24 & -0.37 & 0.13 & 0.37 & 0.54 & 0.29 & 0.42 \\
\hline Firm owner background & 0.08 & 0.17 & 0.03 & 0.15 & 0.25 & 0.06 & 0.09 \\
\hline Redundancies & & 0.26 & & & 0.33 & & \\
\hline Rc $c^{2}$ between the canonical variates & & $25.40 \%$ & & & $24.50 \%$ & & \\
\hline \multicolumn{8}{|l|}{ Set 2 Canonical Loadings } \\
\hline \multicolumn{8}{|l|}{ PROJECT PERFORMANCE } \\
\hline Cost Effectiveness & 0.02 & -0.09 & 0.01 & -0.61 & -0.48 & 0.23 & 0.24 \\
\hline Quality & 0.87 & 0.76 & 0.57 & -0.51 & -0.52 & 0.27 & 0.84 \\
\hline Time & -0.66 & -0.52 & 0.27 & -0.65 & -0.69 & 0.48 & 0.75 \\
\hline Redundancies & & 0.28 & & & 0.33 & & \\
\hline
\end{tabular}

Coeff=Standardised Canonical coefficient, $r=$ canonical structure loading, $h 2=$ commonality, $r 2=$ square of canonical structure loading

In canonical root 1 , the redundancies of the criterion and explanatory variables are respectively 0.28 and 0.26 , indicating the combined contributions of the variables to their respective variates. Impliedly, in R2 terms, $28 \%$ of the variance in the explanatory variate is explained by the criterion variate, while the explanatory variate explains $26 \%$ of the variation in the criterion variate.

In canonical root 2 , corporate advantage has a significant canonical structure loading $(\mathrm{r}=0.35)$, but an insignificant coefficient (coeff=-0.01). Therefore, canonical root 2 mainly shows the nexus between firm experience $(\mathrm{r}=0.92$, coeff $=0.83)$ and firm certification $(\mathrm{r}=0.54$, coeff $=0.37)$ on the explanatory side, and costeffectiveness $(\mathrm{r}=-0.48$, coeff $=-0.61)$, quality $(\mathrm{r}=-0.52$, coeff $=-0.51)$, and time $(r=-0.69$, coeff $=-0.65)$. A look at the $\mathrm{r} 2$ shows that firm experience is the major explanatory variable in canonical root 2. Experienced and certificated firms here tend to have projects with time overruns. However, they perform better on cost and quality (both the ratio of the final account value to the initial contract sum and the number of re-works decrease as firm experience and certification increases). Table 11 shows the results of the stability test of the independent variables. It shows that corporate advantage remained consistently significant when the other variables were removed in canonical root 1 , whereas firm certification became insignificant $(\mathrm{r}=0.191)$ when the firm experience was removed. In canonical root 2, however, both firm experience and firm certification were consistently significant $(r \geq 0.3)$ when the other explanatory variables were removed in turns. The results in Table 11 support the interpretation of the data using the consistent variables as already done.

Table 11: Stability test of removal of independent variables

\begin{tabular}{lccccc}
\hline \multirow{2}{*}{ Variables } & Before Omission & \multicolumn{4}{c}{ After the Omission of: } \\
\cline { 3 - 6 } & & $\begin{array}{l}\text { Corporate } \\
\text { Advantage }\end{array}$ & $\begin{array}{l}\text { Firm } \\
\text { Experience }\end{array}$ & $\begin{array}{l}\text { Firm } \\
\text { Certification }\end{array}$ & $\begin{array}{c}\text { Firm Owner } \\
\text { Background }\end{array}$ \\
\hline Canonical Root 1 & & & & & \\
Corporate Advantage & 0.92 & VIR & -0.985 & -0.981 & -0.824 \\
Firm Experience & 0.14 & -0.921 & VIR & -0.554 & 0.064 \\
Firm Certification & -0.37 & -0.533 & 0.191 & VIR & 0.474 \\
Firm owner background & 0.17 & -0.252 & -0.237 & -0.269 & VIR \\
\hline Canonical Root 2 & & & & & 0.147 \\
Corporate Advantage & 0.35 & VIR & -0.082 & -0.819 & 0.560 \\
Firm Experience & 0.92 & 0.315 & VIR & -0.941 \\
Firm Certification & 0.54 & -0.834 & -0.947 & VIR & 0.443 \\
Firm owner background & 0.25 & 0.320 & -0.299 & -0.146 & VIR \\
\hline VIR & & & & &
\end{tabular}

$V I R=$ Variable of interest in the row

\section{Discussion of Findings}

Overall, a significant relationship exists between the firm OE factors and the three project performance variables. For the type of firms of interest here, OE can be 
understood from 'who the firm is' generally. OE centres on the internal resources, processes and organisation of the firm. The finding of this study that the OE of an SME contractor is related to its project performance supports findings in previous studies and justifies the prequalification of contractors by investigating their make-up as well as their efficiency as a firm (Khosrowshahi, 1999). Sawacha et al. (1999) identified organisational factors as among the group of factors affecting the project safety performance of projects. In this study, organisational factors, although differently measured, were found to be related to project quality, cost and time performance, which were not measured in Sawacha et al. (1999). This study additionally offers insights on the summary of the OE variables that are related to project performance, namely, corporate advantage, firm experience and firm certification. This finding generally aligns with that of Alzahrani and Emsley's (2013) who found that firm resources, expertise, and organisation are among firm-level variables that affect project success at the site-level. For instance, the variable firm size loaded highly under corporate advantage in this study and loaded highly under organisation in Alzahrani and Emsley (2013). This study, however, adds firm certification to the organisational factors required for the project-level performance of construction SMEs.

\subsection{Corporate advantage of the firm and project performance}

The significant loadings of previous self-employment, firm size, ownership of other businesses and group membership support the argument that corporate advantage is a latent variable in the set of explanatory variables of the study. Firms whose owners own other companies as well tend to be bigger and the owners tend to have previous self-employment. Collis and Montgomery (1998) viewed corporate advantage as centred around synergising resources across multiple businesses to optimise organizational performance. The study, however, referred to big corporations mostly outside of construction industry and developing country contexts. SME contractor owners who also own other businesses tend to form small "corporations" where the resources of the companies are synergistically pooled together. Resultantly, such contractors become better positioned than their peers to perform at the site level following Ljubojevic, Ljubojevic and Maksimovic's (2013) argument. Thus, ordinarily, the effectiveness of the firm should increase as the corporate advantage gets better. This study, however, indicated a negative association between project time and quality performance and a construction SME's corporate advantage. Brush, Bromiley, and Hendrickx (1999) found a sizable organizational effect on business segment performance, using data from the United States of America corporations. The companies used were not restricted to SMEs and the construction industry, and therefore, differ from the context of this study. In this case, firms with better corporate advantages had lower planned durationactual duration ratios due to reworks. The SME contractors failed to replicate their organisational strengths at site levels. The data for this study shows that corporate advantage, as measured in this study, does not guarantee better project outcomes in terms of early completion and less rework.

\subsection{Firm experience and project performance}

Firms can only do what they know (Dimov \& de Holan, 2010). Firm experience, as noted by Dimov and de Holan (2010), is the sum of what the firm knows by itself and what it has learned from others. Firm experience was the second factor identified through factor analysis and supported by variables such as firm experience and construction industry work experience of the company owner, among others. The explanatory variable "firm experience" was measured in this study based on the types of projects a firm has been involved in, while the "construction industry work experience" of the owner was measured in terms of years of construction industry work. Both measures are in tandem with Dimov and de Holan's (2010) view that firm experience depends both on length of time in the industry as well as on the spread of experience within the industry. Firm experience is vital in appraising the OE of an SME contractor since it aids the mitigation of risks (Akintoye \& MacLeod, 1997). The findings of this study suggest that while firm experience aids cost and quality performances, schedule overruns grow worse as the experiences of the firms tended to increase. Time overruns have been a major problem for construction projects, which firm experience does not solve. As evidenced by the findings of this study, more experienced SME contractors make more claims for time than the relatively newer firms, which leads to schedule growths.

\subsection{Firm experience and project performance}

Firm certification in this study refers to the level of a firm's categorisation in its registration with the BPP. The BPP's classification is based on a contractor's equipment, personnel and financial capacities, and determines the Naira value of projects the federal government can award the firm. It also refers to the number of client organisations with which the firm is registered. Organisations (both private and public) often require prior registration for contractors to be included in a shortlist of firms that can tender for projects within such organisations. Besides this, contractors for federal government projects in Nigeria are expected to contribute to or be registered with several national institutions such as the Industrial Training Fund and the National Pension Commission (BPP, 2018). The ability of a contractor to be certified/registered by these institutions is a determinant of its $\mathrm{OE}$ because non-registration can negate the contractor's chances of success during prequalification to tender for projects. The firm certification was the third factor identified in the factor analysis and was supported by several registrations and level of firm registration. In canonical root 2 , firm certification tended to be associated with time overruns, but lessened project cost and amount of rework. The stability test established that highly certificated SME contractors perform better on project cost and quality performances.

\subsection{Firm owner-background and project performance}


SMEs are often owned by individuals whose personalities have overbearing influence on the $\mathrm{OE}$ of the firms. An SME contractor may be awarded contracts based solely on the personality of its owner. Barrett and Sexton (2006) pointed out that owners of SME construction firms bear the burden of making quick decisions and creating innovative activities to counter shifting client demands and market conditions. Several studies found that firm owner qualities like firm age are tied to firm survival (Cressy, 1996; Madhoushi \& Ghaedi, 2013). Despite this, this study shows no significant influence of firm owner background in terms of ethnicity of the owner on project performance for the studied SME contractors. It means that the ethnicity of a construction SME owner is irrelevant to the performance of a project, hence nepotism in contract awards (Le et al. 2014) do not lead to better project performance. Thus, considered entirely from the client's perspective, the firm owner background does not explain an SME contractor's performance on a project.

\section{Conclusion}

This study sought to evaluate the determinants of OE within SME construction firms, and to investigate the influence of these on the outcomes of projects executed by such firms. From the contractors' perspective, four firm domains were identified for investigating $\mathrm{OE}$ among the genre of firms covered by this study, namely: corporate advantage, firm experience, firm certification and firm owner background. These domains are the contractors' focus on rating their own OE. When viewed from the client's perspective, it was found that contractors who excelled in these domains still had schedule growths. Findings from this study, however, show that firm certification and experience enhance project performance in terms of quality and cost since more certificated and experienced firms have fewer rework and lower final account value-to-initial contract sum ratio in their projects.

\section{References}

Abor, J. and Quartey, P., 2010. Issues in SME development in Ghana and South Africa. International research journal of finance and economics, 39(6), pp.215228.

Acar, E., Kocak, I., Sey, Y. and Arditi, D., 2005. Use of information and communication technologies by small and medium-sized enterprises (SMEs) in building construction. Construction Management and Economics, 23(7), pp.713-722.

Aibinu, A. A. and Jagboro, G. O., 2002. The effects of construction delays on project delivery in Nigerian construction industry. International Journal of Project Management 20 (2002), pp. 593-599

Akintoye, A.S. and MacLeod, M.J., 1997. Risk analysis and management in construction. International journal of project management, 15(1), pp.31-38.

Alutu, O. E., 2007. Unethical practices in Nigerian construction industry: Prospective engineers' viewpoint. Journal of Professional Issues in Engineering Education and Practice, 133(2), pp. 84-88.
Regarding the influences of corporate advantage, firm certification and experience on project performance, clients should show preference to firms with better certification and experience than to firms that merely have corporate advantage irrespective of the firm owner's background. Firms with better corporate advantage tend to re-do their work more often, and so last longer on projects with insignificant improvements on project cost performance. A firm's experience causes it to make fewer mistakes during construction and by so doing, make savings which favour the client.

Construction stakeholders, and indeed, the general public, should beware of SME contractors that only boast of good corporate advantage and ownership by prominent persons in the society, but without adequate certification and experience. Based on the results of this study, a highly performing SME contractor cannot be known by the extent of its corporate advantage and firm owner background, but by the level of its certification and experience. Public procuring entities engaging SME contractors should assess the firms based on firm experience and certification. The results of this study justify the requirements for registrations and certifications prior to tendering, and this should be retained, especially, by public tertiary institutions in the study area. SME contractors should explore every avenue of gaining experience, which will improve their $\mathrm{OE}$ and project performance.

It is acknowledged that the sample size of this research needs to be higher and accommodative of projects in other kinds of organisations other than educational institutions. Findings in this study, however, justify future studies on how the OE of contractors relates to other variables of project performance. Further studies should also explore the intercepts between construction project management and organisational effectiveness theories.

Alzahrani, J.I. and Emsley, M.W., 2013. The impact of contractors' attributes on construction project success: A post construction evaluation. International Journal of Project Management, 31(2), pp.313-322.

Ameh, O.J., Soyingbe, A.A. and Odusami, K.T., 2010. Significant factors causing cost overruns in telecommunication projects in Nigeria. Journal of Construction in Developing Countries, 15(2), pp.49-67.

Argyris, C., 1964. Integrating the individual and the organisation. New York: Wiley

Babajide, A., 2012. Effects of Microfinance on Micro and Small Enterprises (MSEs) Growth in Nigeria Asian Economic and Financial Review, 2(3), pp. 463-477.

Bank of the Industry, 2018. MSME's definition. Viewed August 16, 2018 from https://www.boi.ng/smedefinition/

Barrett, P., and Sexton, M., 2006. Innovation in small, project-based construction firms. British Journal of Management, 17(4), pp. 331-346.

Baselga-Pascual, L, Trujillo-Ponce, A., Vähämaa, E. and Vähämaa, S., 2014. Ethical reputation of financial institutions: Do board characteristics matter? Retrieved 
June 25, $2015 \quad$ from http://www.researchgate.net/publication/265906701

Bassioni, H. A., Price, A. D., and Hassan, T. M. 2004. Performance measurement in construction. Journal of management in engineering, 20(2), pp. 42-50.

Borghesi, R., Houston, J., and Naranjo, A., 2007. Value, survival, and the evolution of firm organizational structure. Financial Management, 36(3), pp. 5-31

Brush, T.H., Bromiley, P. and Hendrickx, M., 1999. The relative influence of industry and corporation on business segment performance: an alternative estimate. strategic management journal, 20(6), pp.519-547.

Bureau of Public Procurement (2015). Summary of Petitions Received From January to June 2015. Retrieved from

http://www.bpp.gov.ng/index.php?option=com_joomdoc $\&$ view=documents \&path=Summary+Of + Petitions + Rece ived+From+January+To+June+2015.pdf

Bureau of Public Procurement (2018). Contractors, Consultants and Service Providers Categorized and Classified On National Database. Retrieved from http://www.bpp.gov.ng/index.php?option=com_joomdoc $\&$ task=document.download \&path=list-of-classifiedcompanies-on-national-database-1 st-batch $\&$ Itemid $=845$.

Buyinza, F. and Bbaale, E., 2013. Access to credit and the effect of credit constraints on the performance of manufacturing firms in the East African region: Micro analysis. International Journal of Economics and Finance, 5(10), p.85-99.

Cameron, K., 1980. Critical Questions in assessing organisational effectiveness. Organisational Dynamics, (autumn, 1980), pp. 66-80

Cameron, K., 1986. Effectiveness as paradox: consensus and conflict in conceptions of organisational effectiveness. Management Science, 32(5), pp. 539-553

Cameron, K.S. and Whetten, D.A., 1983. Organizational effectiveness: one model or several?. In Organizational Effectiveness (pp. 1-24).

Cefis, E. and Marsili, O., 2005. A matter of life and death: innovation and firm survival obtained from https://feb.kuleuven.be/eng/tew/academic/msi/_docs/wor kshops/2005-11-22.pdf on 18th March, 2015

Cheng, E.W., Li, H. and Love, P.E.D., 2000. Establishment of critical success factors for construction partnering. Journal of management in engineering, 16(2), pp.84-92.

Chen, Y.S., Lai, S.B. and Wen, C.T., 2006. The influence of green innovation performance on corporate advantage in Taiwan. Journal of business ethics, 67(4), pp.331-339.

Cho, K, Hong, T. and Hyun, C. T., 2009. Effect of project characteristics on performance in construction projects based on structural equation model. Expert systems with applications, 36(2009), pp. 10461-10470

Clough, R. H., Sears, G. A., and Sears, S. K., 2000. Construction project management. Hoboken (New Jersey): Wiley

Coleman, S., Cotei, C. and Farhat, J., 2013. A resourcebased view of new firm survival: new perspectives on the role of industry and exit route. Journal of Development Entrepreneurship 18(1), pp. 1 - 25

Collis, D.J. and Montgomery, C.A., 1998. Creating corporate advantage (pp. 71-83). Harvard Business
School. Viewed August 21, 2018 from http://www.akbareftekhari.ir/fa/Files/Paper/CREATING $\% 20$ corporate $\% 20$ advantages.pdf

Cook, R., Campbell, D and Kelly, C., 2012. Survival Rates of New Firms: An Exploratory Study. Small Business Institute Journal, 8(2), pp. 35-42

Cook, P., and Nixson, F., 2000. Finance and small and medium-sized enterprise development. Manchester: Institute for Development Policy and Management, University of Manchester.

Costello, A. B., and Osborne, J. W., 2005. Best practices in exploratory factor analysis: Four recommendations for getting the most from your analysis. Practical assessment, research \& evaluation, 10(7), pp. 19.

Cressy, R., 1996. Are business startups debt-rationed? The Economic Journal, pp.1253-1270.

Crum, M. R., Lund, D. B, and van Auken, H B., 1987. A canonical correlation analysis of Carrier financial strategy: the case of Airline deregulation. Transportation Research Part A. 21(3), pp. 179-190.

Dainty, A., Leiringer, R., Fernie, S., and Harty, C., 2017. BIM and the small construction firm: a critical perspective. Building Research \& Information, 45(6), pp. 696-709.

Darwisha, T. K, Singh, S. and Mohamed, A. F., 2013. The role of strategic HR practices in organisational effectiveness: an empirical investigation in the country of Jordan. The International Journal of Human Resource Management, 24 (17), pp. 3343-3362

Dattalo, P. V. (2014). A demonstration of canonical correlation analysis with orthogonal rotation to

facilitate interpretation, Unpublished manuscript, School of Social Work, Virginia Commonwealth University, Richmond, Virginia

Dean, D. L., Bülent M. and Christopher. P., 2000. Revisiting Firm Characteristics, Strategy, and Export Performance Relationship: A Survey of the Literature and an Investigation of New Zealand Small Manufacturing Firms. Industrial Marketing Management, 29, pp. 461477.

De Wit, A., 1988. Measurement of project success. International journal of project management, 6(3), pp.164-170.

Dimov, D., and Martin de Holan, P. (2010). Firm experience and market entry by venture capital firms (1962-2004). Journal of Management Studies, 47(1), pp. 130-161.

Egesa, K. A., 2011. Indigenous firms' survival in Uganda: is there a role for increased technology use? The Bank of Uganda Journal, 4(1), pp. 81 - 108

Enshassi, A., Al-Hallaq, K., and Mohamed, S., 2006. Causes of contractor's business failure in developing countries: The case of Palestine. Journal of construction in developing countries, 11(2), pp. 1-14.

Etzioni, A., 1964, Modern organisations. Englewood Cliffs, N.J, Prentice Hall.

European Commission, 2003. Evaluation of the SME Definition. Retrieved February 03, 2018, from https://eur-lex.europa.eu/legalcontent/EN/TXT/PDF/?uri=CELEX:32003H0361\&from $=\mathrm{EN}$ 
Farinha, L., 2005. The survival of New Firms: Impact of Idiosyncratic and Environmental Factors in Financial Stability Report Banco de Portugal obtained from https://www.bportugal.pt/en-US/.../AR200501_e.pdf on 5th July, 2014

Federal Republic of Nigeria, 2007. Public Procurement Act (2007). Retrieved from http://www.bpp.gov.ng/index.php?option=com_joomdoc $\&$ view=documents\&path $=$ Public $\% 20$ Procurement $\% 20 \mathrm{~A}$ ct $\% 202007$ pdf.pdf \&Itemid $=614$

Fellows, R. and Liu, A., 1997. Research Methods for Construction. Oxford:

Blackwell Science Ltd.

Field, A., 2005. Exploratory factor analysis. Discovering statistics using SPSS, pp.619-680.

Fox, P. and Skitmore, M., 2007. Factors facilitating construction industry development. Building Research and Information, 35(2), pp.178-188.

Frankish, J., Roberts, R. and Storey, D., 2007. Business Survival and Entrepreneurial Learning, Institute of Small Business and Entrepreneurship 7(9), pp. 1-17

Georgopoulos, B.S. and Tannenbaum, A.S., 1957. A study of organizational effectiveness. American Sociological Review, 22(5), pp.534-540.

Geroski, P. A., Mata, J. and Portugal, P., 2003. Founding Conditions and the Survival of New Firms, Banco De Portugal Economic Research Department obtained from www.druid.dk/uploads/tx_picturedb/wp07-11.pdf on 3 June 2014

Grix, J., 2002. Introducing students to the generic terminology of social research. Politics, 22(3), pp.175186.

Guariglia, A. and Bridges, S., 2008. Financial constraints, global engagement, and firm survival in the United Kingdom : evidence from micro data.', Scottish Journal of Political Economy., 55 (4). pp. 444-464

Hair, J. F., Anderson, R. E., Tatham, R. L. and Black, W.C., 1998. Multivariate Data Analysis, 5th edition. New Jersey: Prentice Hall

Hardcastle, C., Edwards, P. J., Akintoye, A., and Li, B., 2005. Critical success factors for PPP/PFI projects in the UK construction industry: a factor analysis approach. Construction management and economics, 23(5), pp. 459471.

Holbeche, L., 2012. Organisational effectiveness: A fresh mindset. People Management, 2, pp. 32-37.

Hwang, B.G., Thomas, S.R., Haas, C.T. and Caldas, C.H., 2009. Measuring the impact of rework on construction cost performance. Journal of construction engineering and management, 135(3), pp.187-198.

Ibrahim, I.I., Githae, W., and Stephen, D., 2014. Indigenous contractors involvement and performance in construction procurement systems in Nigeria. Global Journal of Research In Engineering. 14(1), pp. 1-15

Idoro, G.I., 2010. Influence of quality performance on clients' patronage of indigenous and expatriate construction contractors in Nigeria. Journal of Civil Engineering and Management, 16(1), pp.65-73.

Idoro, G. I., 2012. Influence of the Monitoring and Control Strategies of Indigenous and Expatriate Nigerian Contractors on Project Outcome. Journal of Construction in Developing Countries, 17(1) 2012, 49-67
Iyer, K. C. and Jha, K. N., 2005. Factors affecting cost performance: evidence from Indian Projects. International Journal of Project Management, 23(2005), pp. 283-295

Jonkers, H., Lankhorst, M. M., ter Doest, H. W., Arbab, F., Bosma, H., and Wieringa, R. J., 2006. Enterprise architecture: Management tool and blueprint for the organisation. Information systems frontiers, 8(2), pp. 6366.

Keramati, A., 2007. Assessing the Effects of Information Technology on Firm Performance Using Canonical Correlation Analysis: A Survey in Iran Car Part Suppliers Sector. Proceedings of World Academy of Science, Engineering and Technology 21(May 2007), pp. 392-399.

http://citeseerx.ist.psu.edu/viewdoc/download?doi=10.1. 1.116.4880\&rep=rep1\&type $=$ pdf

Kheni, N. A., Gibb, A. G. F. and Dainty, A. R. J., 2010. Health and safety management within small and mediumsized enterprises (SMEs) in developing countries: study of contextual influences. Journal of Construction Engineering and Management, 136(10), pp. 1104-1115

Khosrowshahi, F., 1999. Neural network model for contractors' prequalification for local authority projects. Engineering construction and architectural Management, 6(3), pp.315-328.

Kiziltas, S., Dikmen, I, and Birgonul, M. T., 2003. Organisational Effectiveness in construction: a conceptual framework. In: Greenwood, D. J. (Ed.), 19th Annual ARCOM

Conference, 3-5 September 2003, University of Brighton. Association of Researchers in Construction Management, 2, pp. 523-32

Kulemeka, P.J., Kululanga, G. and Morton, D., 2015. Critical Factors Inhibiting Performance of Small-and Medium-Scale Contractors in Sub-Saharan Region: A Case for Malawi. Journal of Construction Engineering, 2015, 1-17.

Kunt,A. D., Klapper, L. F. and Panos, G. A., 2007. The origins of self-employment. Retrieved June 27, 2015 from http://siteresources.worldbank.org/INTFR/Resources/Bo sniaFeb07Klapperetal.pdf

Le, Y., Shan, M., Chan, A. P., and Hu, Y., 2014. Overview of corruption research in construction. Journal of management in engineering, 30(4), pp. 02514001-102514001-7. 10.1061/(ASCE)ME.1943-5479.0000300

Leung, M.Y., Ng, S.T., Skitmore, M. and Cheung, S.O., 2005. Critical stressors influencing construction estimators in Hong Kong. Construction Management and Economics, 23(1), pp.33-44. doi:10.1080/01446190410001678099

Ljubojevic, C., Ljubojevic, G. and Maksimovic, N., 2013. Corporate Governance and Competitive Capability in Serbian Companies (pp. 101-112). University of Primorska, Faculty of Management Koper.

Loosemore, M, Dainty, A and Lingard, H., 2003. Human Resource Management in Construction Projects: Strategic and Operational Approaches. New York: Spon Press

Love, P. E. D. and Skitmore, M., 1996. Approaches to organisational effectiveness and their applications to construction organisations. In: Thorpe, A., (Eds.), Proceedings of the 12th Annual Conference and Annual General Meeting of the Association of Researchers in 
Construction Management, 11-13 September, Sheffield Hallam University, Sheffield, pp. 378-87

Love, P. E., and Holt, G. D., 2000. Construction business performance measurement: the SPM alternative. Business process management journal, 6(5), pp. 408-416.

Malacarne, R. L. 2014. Canonical correlation analysis. Mathematica Journal, 16 (66), pp. 1-22

Madhoushi, M. \& Ghaedi, M., 2013. Founder's characteristics and firm survival: Iranian study. World Applied Programming, 3(10), pp. 504-511

Martins, N. and Coetzee, M., 2009. Applying the Burke-Litwin model as a diagnostic framework for assessing organisational effectiveness. SA Journal of Human Resource Management, 7(1), pp.1-13. Mendes, A. B., da Sylva, E. S., Santos, J. M. A. (2012) Efficiency measures in the agricultural sector with applications, Netherlands: Springer

Mbugua, L.M., Harris, P., Holt, G.D. and Olomolaiye, P.O., 1999, September. A framework for determining critical success factors influencing construction business performance. In Proceedings of the Association of Researchers in Construction Management 15th Annual Conference (Vol. 1, pp. 255-64).

Mendes, A. B., da Sylva, E. S., Santos, J. M. A., 2012. Efficiency measures in the agricultural sector with applications. Netherlands: Springer

Mohd, K. H., 2005. Small and Medium-Sized enterprises in Malaysia-Role in Issues. Sintok: UUM Press.

Montabon, F., Sroufe, R., and Narasimhan, R., 2007. An examination of corporate reporting, environmental management practices and firm performance. Journal of operations management, 25(5), pp. 998-1014.

Munro, B. H., 2005. Statistical Methods for health care research fifth edition, Philadelphia: Lippincott

Williams and Wilkins

Nafziger, E. W. and Terrell, D., 1996. Entrepreneurial human capital and the long-run survival of firms in India, World Development 24(4), pp. 689-696

Nelson, S., Brunetto, Y., Farr-Wharton, R., and Ramsay, S., 2007. Organisational effectiveness of Australian fast growing small to medium-sized enterprises (SMEs). Management Decision, 45(7), pp. 1143-1162.

Ng, S. T., Cheng, K. P., and Skitmore, R. M., 2005. A framework for evaluating the safety performance of construction contractors. Building and environment, 40(10), pp. 1347-1355.

Odediran, S.J. and Windapo, A.O., 2014, February. Systematic review of factors influencing the cost performance of building projects. In Postgraduate Conference (p. 501).

Ofori, G., 1991. Programmes for improving the performance of contracting firms in developing countries: A review of approaches and appropriate options. Construction Management and Economics, 9(1), pp.1938.

Ofori, G., 2000, November. Challenges of construction industries in developing countries: Lessons from various countries. In 2nd International Conference on Construction in Developing Countries: Challenges Facing the Construction Industry in Developing Countries, Gaborone, November (pp. 15-17).
Ogbu, C. P., 2011. Risk management practices of multinational and indigenous construction companies in Nigeria: a comparative analysis. Journal of Research in National Development, 9(2), pp. 315-324

Ogbu, C.P., 2018. Survival practices of indigenous construction firms in Nigeria. International Journal of Construction Management, 18(1), pp.78-91.

Panas, A. and Pantouvakis, J. P., 2010. Evaluating Research Methodology in Construction Productivity Studies. The Built \& Human Environment Review, 3(1), pp. $63-85$

Rencher, A. C., 2002. Methods of Multivariate Analysis (2nd edition). Canada: John Wiley \& Sons Inc.

Rozemeijer, F.A., 2000. Creating corporate advantage in purchasing. Technische Universiteit Eindhoven. Viewed August 21, 2018 from https://www.researchgate.net/profile/Frank_Rozemeijer/ publication/241849648_Creating_Corporate_Advantage _in_Purchasing/links/56e1dc7c08ae3328e076b063.pdf

Sawacha, E., Naoum, S. and Fong, D., 1999. Factors affecting safety performance on construction sites. International journal of project management, 17(5), pp.309-315.

Sexton, M., Barrett, P., and Aouad, G., 2006. Motivating small construction companies to adopt new technology. Building Research \& Information, 34(1), pp. $11-22$

Sherry, A and Henson, R. K., 2005. Conducting and Interpreting Canonical Correlation

Analysis in Personality Research: A User-Friendly Primer, Journal of Personality Assessment, 84(1), pp. 3748

Shafto, M.G., Degani, A. and Kirlik, A., 1997, October. Canonical correlation analysis of data on humanautomation interaction. In Proceedings of the Human Factors and Ergonomics Society Annual Meeting (Vol. 41, No. 1, pp. 62-65). Sage CA: Los Angeles, CA: SAGE Publications.

Shaver, J. M., Mitchell, W and Yeung, B., 1997. The effect of own-firm and other-firm Experience on foreign direct investment Survival in the united states, 1987-92. Strategic Management Journal, 18, pp. 811-824

Stare, A., 2011. The impact of the organisational structure and project organisational culture on project performance in Slovenian enterprises. Management: journal of contemporary management issues, 16(2), pp. 122.

Song, L., Mohamed, Y. and AbouRizk, S.M., 2009. Early contractor involvement in design and its impact on construction schedule performance. Journal of Management in Engineering, 25(1), pp.12-20.

Takim, R. and Akintoye, A., 2002, September. Performance indicators for successful construction project performance. In 18th Annual ARCOM Conference (Vol. 2, pp. 545-555).

Tam, C. M., 1992. Discriminant Analysis Model for predicting contractor performance in Hong Kong; A doctorial thesis submitted in partial fulfillment of the requirements for the award of Doctor of Philosophy of Loughborough University of Technology

Upadhaya, B., Munir, R., and Blount, Y., 2014. Association between performance measurement systems and organisational effectiveness. International Journal of 
Operations \& Production Management, 34(7), pp. 853875.

Winch, G., 1998. Zephyrs of creative destruction: understanding the management of innovation in construction. Building research \& information, 26(5), pp. 268-279.

Yang, T. and Zhao, S., 2014. CEO Duality and Firm Performance: evidence from an exogenous shock to the competitive environment. Retrieved June 25, 2015 from http://www.bath.ac.uk/management/news_events/events/ corp-cgr-2013/pdf/ZhaoShan.pdf

Yong, A.G. and Pearce, S., 2013. A beginner's guide to factor analysis: Focusing on exploratory factor analysis.
Tutorials in quantitative methods for psychology, 9(2), pp.79-94.

Yuchtman, E. and Seashore, S. E., 1967. A System Resource Approach to Organizational Effectiveness. American Sociological Review 32(6), pp. 891-903

Yukl, G., 2008. How leaders influence organisational effectiveness. The Leadership Quarterly 19 (2008), pp. 708-722

Zhao, X., Hwang, B. G., Pheng Low, S., and Wu, P., 2014. Reducing hindrances to enterprise risk management implementation in construction firms. Journal of Construction Engineering and Management, 141(3), 04014083. DOI: $\quad 10.1061 /(\mathrm{ASCE}) \mathrm{CO} .1943$ 7862.0000945 